Otherwise, apart from the small outbreak in 1977, the figures have remained constant. Reviewing patients in Scotland, Bell et al suggested that cases were being overlooked because paralytic poliomyelitis was becoming forgotten but there was no evidence of this in the results from England and Wales. ${ }^{10}$

Given that the use of inactivated vaccine would have prevented these cases of recipient paralytic poliomyelitis, what would be the effect if Britain switched from the oral to the injected (inactivated) form? If about four fifths of the children continued to be immunised, then each year at least a fifth of the under 1 year olds would be completely unprotected. This percentage might rise if the vaccination rate fell-as it might if injected vaccine replaced the more acceptable oral vaccine. In England and Wales vaccine viruses circulate widely and help to maintain the high seroimmunity rate in the population. Thus the unvaccinated would continue to be at risk of developing contact poliomyelitis, which has a slightly higher rate of paralysis than recipient poliomyelitis. While the population maintains its high immunity introducing a wild virus would be unlikely to result in an epidemic. If inactivated vaccine completely replaced the oral form, however, then these circulating viruses would gradually disappear and as more children became unprotected the herd immunity might not be sufficient to protect them. There is a strong social class bias in the uptake of vaccination, so that pockets of unprotected children might come to be formed. Kubli and others, reporting on the importation of poliomyelitis to industrialised nations in 1975-84, recommended that all travellers, immigrants, refugees, and foreign workers should be immunised against all three polioviruses by routine vaccination (p 169). In Britain, with its many outside contacts, it is unlikely that both wild and vaccine strains would not be introduced, and hence it is essential to maintain the present herd immunity.

Similar discussions are going on in other countries, and Ogra and Faden have suggested that inactivated vaccine should be used for all first doses followed by the oral preparation for the remainder." This scheme would maintain the herd immunity by keeping up the circulating vaccine strains while using the inactivated vaccine for the more vulnerable vaccinees. Nevertheless, it presupposes that the immunity gained by using both types is as high as that gained by the exclusive use of one or the other. Provided it had been carefully evaluated, such a flexible approach to this problem would be well worth considering as it might help to reduce vaccine associated paralytic poliomyelitis.

Roma Chamberlain

Retired Epidemiologist

Cambridge CB3 0NE

1 World Health Organisation Consultative Group. The relationship between acute persisting spinal paralysis and poliomyelitis vaccine-results of a ten-year enquiry. Bull WHO 1982;60:231-3.

2 Hovi T, Cantell K, Huovilainen A, et al. Outbreak of paralytic poliomyelitis in Finland: widespread circulation of antigenically altered poliovirus type 3 in a vaccinated population. wancet 1986;i:1427-32.

3 Mortimer PP, Cunningham P. Sero-immunity to poliovirus in children and young women: England 1972-4. F Hyg(Lond) 1975;74:283-7.

4 Codd AA, White E. Protection against poliomyelitis. Lancet 1977;ii: 1078.

5 Bainton D, Freeman M, Magrath DI, Sheffield F, Smith JWG. Immunity of children to diphtheria, tetanus and poliomyelitis. BrMed $\mathcal{F}$ 1979;i:854-7.

6 Roebuck M, Chamberlain R. Prevalence of antibodies to poliovirus in 1978 among subjects aged 0-88 years. Br Med J 1982;284:697-700.

7 White PBM, Gree J. Prevalence of antibody to poliovirus in England and Wales 1984-6. Br Med $\mathcal{F}$ 1986;293:1153-5.

8 Lamy ME, Cornu C, Desmyter J. Poliovirus antibodies in age groups: an assessment of obligatory vaccination in Belgium. In: International Association of Biological Standardisation, ed. International symposium on immunisation: benefit versus risk factors Brussels 1978. Basle: Karger, 1979:207-13.

9 Begg N, Roebuck M, Chamberlain R. Paralytic poliomyelitis in England and Wales 1970-84. f Hyg (Lond) (in press).

10 Bell EJ, Riding MH, Grist NR. Paralytic poliomyelitis: a forgotten diagnosis? $\mathrm{Br} \mathrm{Med} \mathrm{J}$ 1986;293:193-4.

11 Ogra PL, Faden HS. Polio vaccines: live or dead. 7 Pediatr 1986;108:1031-3.

\section{Managing psychopathic offenders: a problem that will not go away}

One in four of the 1600 patients detained in the special hospitals in England suffers from a psychopathic disorder.' Most have been sent there by the courts after conviction for serious crimes of violence. Their detention is of indeterminate length, and their discharge under section 41 of the Mental Health Act is at the discretion of the Home Secretary. Psychopathic disorder as legally defined depends on abnormal aggression or serious irresponsibility, and treatment must be likely to alleviate or prevent a deterioration. ${ }^{2}$ What treatment are such patients receiving and how are their doctors to decide when they are safe to be discharged?

Unlike the American fictional hero, Randle Patrick McMurphy of One Flew Over the Cuckoo's Nest, ${ }^{3}$ psychopaths detained in England do not receive electroconvulsive therapy or prefrontal leucotomies. The disorder is one of behaviour and socialisation, and the mainstay of treatment is the therapeutic milieu of the special hospitals. ${ }^{4}$ In this environment - likened by one patient to that of a "grown up children's home"s - life is orderly, social interactions are controlled, the havoc unleashed by alcohol or drug intoxication is absent, and a perimeter fence protects the public from the patients and the patients from life. Grounds et al have recently described the combination of group and individual psychotherapy, social skills training, and personality assessments used at Broadmoor. ${ }^{5}$ Measurements of penile tumescence as a putative indicator of sexual preference and drive have also been employed. ${ }^{6}$

These techniques may be interesting time fillers in a special hospital, but what use are they in predicting the future behaviour of psychopaths? The answer, though important, may be irrelevant in the light of important findings from Dell and others at the Institute of Psychiatry in London. ${ }^{7}$ They showed that the main determinant of the length of stay for the psychopathic offender is not what happens to him in hospital but the nature of the crime he committed before he ever got there. For psychopathic offenders violent assaults (particularly if directed against a stranger or if sexual) were associated with longer periods of detention. By contrast, in those patients suffering mental illness (mostly schizophrenia) severity and chronicity of the illness and not the nature of the offence were associated with longer detention.

Since 1984, in common with other patients detained under section 41 of the Mental Health Act, psychopathic offenders have had the right of appeal against detention to a mental health review tribunal. ${ }^{2}$ Called on to explain the clinical and not the protective reasons for the continued detention of psychopaths, psychiatrists may find themselves on shaky ground. Of 38 psychopathic offenders discharged by tribunals from special hospitals in two years, four have subsequently committed a serious offence similar to their original crime. The Home Office, which actually opposed some of these discharges but was powerless to prevent them, wanted legislative change. Consequently a consultative paper that identified the problems was put out last year jointly by the Department of Health and Social Security and the Home Office $^{8}$; its discussion was short on objective evidence, and the recommendations met with opposition. ${ }^{910}$ After an interdepartmental wrangle the proposals were abandoned. ${ }^{\prime \prime}$ 
The problems, however, will not go away, and psychiatrists are still required to advise the Home Secretary about psychopaths detained in hospital. The wisest counsel they can give relates not to the discharges of psychopaths but to their admission. The very existence of psychopathic disorder as one category of mental disorder in the Mental Health Act has attracted fierce debate for decades, ${ }^{12}$ and the Butler report cogently concluded in $\mathbf{1 9 7 5}$ that in medical terms the condition was not treatable. ${ }^{13}$ Three follow up studies of patients from special hospitals concluded that those with psychopathic disorders are more likely than most other groups to reoffend..$^{1416}$ Moreover, hospital orders are intended for offenders who irrespective of their offence warrant compulsory admission. ${ }^{17}$ Yet few psychopaths in Britain are detained under civil powers in general psychiatric practice. In Scotland psychopathic patients now account for less than one in 10 of the population at the state hospital, ${ }^{18}$ while in Northern Ireland new legislation specifically precludes their detention. ${ }^{19}$

We should be concerned at the compulsory confinement in hospital of psychopathic offenders who, were it not for psychiatric intervention, would be in prison. Dell's research supports what many psychiatrists have long suspected - that the treatment given to psychopaths in special hospitals bears an uncanny resemblance to the emperor's new clothes. Many questions await answers. How do psychiatrists know when the condition has been alleviated? What is the relation between alleviation in hospital and life outside? What clinical features distinguish the handful of psychopathic offenders sent each year to special hospitals from the 11000 violent or sex offenders who received prison sentences in $1985 ?^{20} \mathrm{In}$ our present state of clinical knowledge picking out a few psychopaths for compulsory but uncertain treatment may be unfair for these patients, hazardous for their psychiatrists, and misleading for the public.

Senior Lecturer in Forensic Psychiatry,

Derek Chiswick

University Department of Psychiatry,

Royal Edinburgh Hospital,

Edinburgh EH10 5HF

1 Department of Health and Social Security. Special hospital patient statistics 1985. London: DHSS 1986.

2 Mental Health Act, 1983. London: HMSO. 1983.

3 Kesey K. One flew over the cuckoo's nest. London: Pan Books, 1973.

Hamilton JR. The special hospitals. In: Gostin L, ed. Secure provision: a review of special services for the mentally ill and mentally handicapped in England and Wales. London: Tavistock, 1985: the mentall

5 Grounds AT, Quayle MT, France J, Brett T, Cox M, Hamilton JR. A unit for "psychopathic disorder" patients in Broadmoor Hospital. Med Sci Law 1987;27:21-31.

6 Crawford DA. Applications of penile response monitoring to the assessment of sexual offenders. In: West DJ, ed. Sex offenders in the criminal justice system. Cambridge: Institute of Criminology 980:150-61.

Dell S, Robertson G, Parker E. Detention in Broadmoor: factors in length of stay. Br $\mathcal{P}$ Psychia 1987;150:824-7.

Department of Health and Social Security, Home Ofice. Offenders suffering from psychopathic disorder. London: DHSS and Home Office, 1986.

9 Royal College of Psychiatrists. Response to DHSS, Home Office consultative document-offender suffering from psychopathic disorder. London: Royal College of Psychiatrists, 1986.

10 Anonymous. Dealing with mentally disordered offenders classified as psychopathic. Criminal Law Review 1986;November:705-7.

11 Webster P. Home Office fails to curb release of psychopaths. The Times 1986 Dec 22:5 (col 1).

12 Lewis A. Psychopathic personality: a most elusive category. Psychol Med 1974;4:133-40.

12 Lewis A. Psychopathic personality: a most elusive category. Psychol Med 1974;4:133-40. abnormal offenders. London: HMSO, 1975. (Cmnd 6244.)

14 Norris M. Integration of special hospital patients into the community. Aldershot: Gower, 1984

15 Black DA. A 5-year follow-up study of male patients discharged from Broadmoor Hospital. In Gunn J, Farrington DP, eds. Abnormal offenders, delinquency and the criminal-justice system. Chichester: Wiley, 1982:307-24.

16 Tennent G, Way C. The English special hospital-a 12-17 year follow-up study: a comparison of violent and non-violent re-offenders and non-offenders. Med Sci Law 1984;24:81-91.

17 Gunn J. Management of patients who have committed offences. In: Roth M, Price JS, Cawley R, Paykel E, eds. Readings in psychiatry. Oxford: Medical Education (International), 1980:51-3.

18 State Hospital. Annual report 1985. Carstairs: State Hospital, 1986.

19 The Mental Health (Northern Ireland) Order, 1986. London: HMSO, 1986.

20 Home Office. Criminal statistics England and Wales 1985. London: HMSO, 1986. (Cmnd 10.)

\section{RAKE's progress}

After six years as treasurer of the BMA Dr R A Keable-Elliott has handed over to Dr Alistair Riddell. RAKE's achievements are obvious to anyone visiting BMA House. When he came to office the Great Hall was ridiculed as the most expensive badminton court in Europe; it stood empty day after day simply because it failed to meet acceptable standards of acoustics, warmth, or fire safety. Tony KeableElliott determined to develop it into a modern library with committee rooms above, brushing aside the nay sayers and obstacles that had been thought insuperable-planning permission and finance. The results were universally acclaimed, pleasing library users, architectural enthusiasts, and committee members alike. Perhaps the most pleasing comment came from the daughter of the original architect, Lutyens; in the $B M \mathcal{F}$ last Christmas she described the conversion as showing great sensitivity both architecturally and decoratively.

Importantly the conversion of the Great Hall exercise was self financing: the release of former committee rooms and the old Nuffield Library meant that these could be modernised and let at commercial rents. A similar self financing conversion throughout BMA House has meant that new tenants are competing for modernised offices in what is now a much cleaner and brighter building. The BMA's finances are similarly healthy, with an annual income of $£ 8.6 \mathrm{~m}$ and reserves of $£ 12 \mathrm{~m}$. And throughout his six years the former treasurer has been a good friend of the $B M \mathcal{F}$, encouraging it to build healthy reserves as well as to develop new projects such as a larger book publishing programme and a relaunch of the Family Doctor series.

Yet what distinguishes Tony Keable-Elliott from other astute financial experts is his humanity. Both in private and in public he has continued the moderate medicopolitical stance that characterised his chairmanship of the General Medical Services Committee. In line with this humanity one of his last acts as treasurer was "not to oppose officially" a motion of the Annual Representative Meeting that had important financial implications. By supporting an open vote on whether the BMA should contribute to the Medical Education Trust, established to help medical students in need, he ensured that the new generation of intending doctors will receive the profession's sympathy and help.

Editor, $B M \mathcal{F}$. 